\title{
Traditional games in central java coastal in improving the motor ability of early childhood
}

\author{
Indah Lestari ${ }^{1}$, Richma Hidayati ${ }^{2}$ \\ 12 Universitas Muria Kudus, Jawa Tenggah - Indonesia, (indah.lestari@umk.ac.id)
}

\begin{abstract}
The traditional coastal games of Central Java have their own characteristics that are made and developed according to the cultural characteristics of the people of Central Java. Manufacturer games such as online games, video games began to replace the existence of traditional games, even the traditional game is considered as an ancient game, children prefer to choose a game from the factory that tend not to require physical movement excessive. Whereas if performing a traditional game, the child will need a thorough body movement for rough and smooth motor. For that it takes the understanding that precisely in the presence of motor movements of children or movement by the whole body of the child will provide development not only in the element of social maturity and brain enhancement of children to the fullest. But will be able to control the development of rough and smooth body movement of the children.
\end{abstract}

Keywords: traditional games, motoricalability, early childhood

\section{Introduction}

The problem of early childhood motoric development emerged along with the development of technology. In the past when humans were not familiar with technology products for children, children had the freedom to play in nature, to use all their physical organs freely and to do good motor activity. The opportunity seems to be limited by modern toy products that tend to be more attractive but does not involve good physical activity in the game. This often triggers the problems caused by the lack of perfect motoric development due to lack of motor activity.

One way that can be used to overcome the problem of development is through play therapy. For that, the game of middle Java coastal can be used as a reference to develop and develop new models more applicable and in accordance with the philosophy of life of the nation's culture. Especially the Javanese who was born there along with social and cultural environment. Strengthening the character of Java is also important to be invested early in order for children to develop in accordance with the personal character of the culture is expected. The selection of traditional Java coastal games is based on the participation of counselors in the effort to express the character of national identity. In addition, traditional Javanese coastal games allow young children to do more optimal motor activity so as to support the development of motoric children.

Traditional games in Indonesia are very glamorous, this is based on the background of game existence in Indonesia that was created or developed based on local potential, such as geographical 
location, local culture, customs, and the purpose of the game itself. On the other hand, traditional shelter in Central Java Javanese developed or created more oriented as a medium to build social interaction among members of society and the spread of Islam. Traditional games exist in Central Java Coast developed or created by the Wali Songo among others are the game cublak suwengcublak, Jamuran, Gundul-gundul pacul, and others. Thus the traditional coastal games of Central Java have their own characteristics that are made and developed according to the cultural characteristics of the people of Central Java.

The traditional coastal game of Central Java has more tips or suggestions on behaving someone who is mostly traditional games accompanied or accompanied by song and movement. Songs and movements further illustrate the joys and movements that can train the motor skills of the child because the movements in the game rinngan lively and fun, thus the traditional game accompaniment tracks in the Central Java Coast can be enabled or developed to provide assistance to children to improve the ability of motriknya. The underlying reasons besides to train the child's motor on the other hand are also to preserve the traditional game on the Central Coast of Java, which today traditional games are starting to shift with the presence of game manufacturers.

The shifting of traditional coastal games of Central Java along with the times and modernization, this is one of the factors that shifted the traditional game on the coast of Central Java. Manufacturing games on the market, such as online gaming, video games, the existence of game manufacturers began to replace the existence of traditional games, even traditional games until the ancient game is said, children prefer game manufacturers who tend not to require physical movement excessive. However, the game or game manufacturer requires less body movement as a whole, while the traditional game requires a thorough body movement both gross movement and smooth movement.

These conditions encourage the birth of Ministerial Regulation OF Education and Culture No. 10 Year 2014 on Guidelines for the Preservation of Traditions. More than that to socialize the essence of the candy is the inclusion of traditional games into the educational curriculum. The fact that there are children who feel bored and tired at the time to follow the learning to train motoric ability both rough and fine motoric ability, this shows the motoric ability of the children is still low, it is also seen in motor learning balance children are still less able to maintain balance, hand movements still stiff or less supple to stimulate or motivate children to practice their motoric ability through traditional games.

\section{Discussion}

The play therapy was first developed in 1930 by the child psychotherapist Hermione HugHellmuth, Anna Freud, and Melanie Klein who aimed to help children deal with emotional and behavioral problems (Drewes and Schaefer, 2010: 8). Game/gaming therapy is a social interaction therapy that provides opportunities to learn socio-emotional skills and improve emotional resilience. While most children learn social skills from observing others or through explicit instruction, others have not learned or do not apply pro social skills and require additional teaching, training and coaching (Plummer, 2010: 24). The natural tendency of children to play provides a very motivating way to engage them in learning pro social skills. Children tend to be individuals who solve problems with aggression, lack of friendship, anger management and liars.

The benefits gained through playing therapy are:

1. Children are 'awake' when dealing with the prospect of 'playing'. They are directly involved in social situations that teach skills while they are having fun. Those who are familiar with elements of play such as guarding rules, winning, losing and cooperative. 
2. Children are actively involved with the process of playing games, social and emotional challenges arise when educating 'or crisis occurs, thus providing a meaningful learning experience immediately.

3. Play therapy children by providing a safe environment to practice new skills. The children feel relaxed and the flow of discussion is easy in this setting.

4. Clinical observations can be made and conclusions are drawn about children who do not increase the use of prosocial skills after extra learning and practice guidance. The existence of organic syndrome, mental health problems or child protection issues need to be investigated.

\section{The Traditional Javanese Game}

Traditional games are often called folk games, a game that grew and grew in the past mainly grown in rural communities. The traditional game grows and develops based on the needs of the local community Most traditional games are influenced by the nature of the environment, because the game is always interesting, entertaining according to the conditions of society at that time.

The traditional game is generally recreative, because many require the creation of children. These games usually reconstruct various social activities in society. Such as: the market that mimics the activity of buying and selling, jaranan imitating people who are traveling with horseback riding, game menthok-menthok that symbolizes laziness.

Traditional games have a strong influence from local culture, therefore the traditional game undergoes changes in the form of changes, additions or reductions in accordance with local conditions. Thus, traditional games even though the game names differ across regions, but have similarities or similarities in how to play them. Traditional games that have grown in the community before this time began to be less well known children as the younger generation. The results of research on these traditional games actually have a wealth of values that can develop various aspects of child development. 57 traditional games that have been identified above are grouped into 3, namely: 1) game play, 2) motion/physical game, and 3) motion and song games (motion accompanied song) as quoted from Seriyati and Hayati (2013)

The games that involve the songs are :(1) Gedang gepeng; (2) Ris- irisan tela; (3) Hanacaraka; (4) Kubuk; (5) Lir-ilir; ;(6) Kursi Jebol; (7) Sinten nunggang sepur.

The games that involve the body movement, antara lain: (1) Balapan sempol; (2) Gendiran; (3) Pathon; (4) Kuncingan; (5) Kasti; (6) Benthik; (7) Sundamanda/ engklek; (8) Gamparan; (9) Gobak sodor; (10) Dakon; (11) Lurah-lurahan; (12) Jentungan/Dehlikan; (13) Obar-abir; (14) Simbar Suru; (15) Tumbaran; (16) Obrog Batu; (17) Ambah-ambah lemah; (18) Sobyung.

The games that involve the song and body movement are:(2) Cungkup milang kondhe; (3) Gula Ganti; (4) Lepetan; (5) Menthog-menthog; (6) Buta-buta galak; (7) Gotri; (8) Kacang goreng; (9) Slukusluku bathok; (10) Siji loro telu; (11) Cublak-cublak suweng; (12); Jamuran; (13) Gundhul-gundhul pacul; (14) Jaranan; (15) Baris rampak; (16) Uler keket; (17) Kidang talun;(19) Bedhekan; (20) Petakpetik; (21) Man Dhoblang; (22) Bang-bang wus rahina; (23) Tuku Kluwih; (24) Pitik walik jambul; (25) Kupu kuwi; (26) Iwak emas;(27) Dhempo; (28) Bethet thing thong; (29) Blarak-blarak sempal; (30) Jo pra kanca; (31) Cah dolan; (32) Aku duwe pitik; (33) Kembang jagung; (34) Sepuran

From all that games wich allow the body movement are: (1) Cublak-cublak Suweng; (2) Jamuran; (3) Gundhul-gundhul PacuL; (4) Jaranan; (5) Uler Keket; (6) Kidang Talun; (7) Kursi Jebol; (8) Lagu Kacang Goreng; (9) Sluku-sluku Bathok; (10) Siji loro telu; (11) Menthog- menthog; (12) Buta-buta Galak; (13) Man Dhoblang; (14) Tuku kluwih; (15) Pitik walik jambul; (16) Kupu kuwi; (17) Iwak emas; (18) Jo pra kanca; (19) Cah dolan; (20) Aku duwe pitik; (21) Bang-bang wis rahina; (22) Kembang jagung; (23) Sepuran. 


\section{Early Childhood Motoric Development}

Motor development coincided with genetic growth process or physical maturity of children, Theory that explains in detail about child motor systemic is Dynamic System Theory developed by Thelen \& Whiteneyerr (Santrock, 2012). The theory reveals that in order to build motor skills children have to perceive something in their environment that motivates them to do something and use their perceptions to move. Motor ability represents the child's desire. For example when children see toys with a wide range, children perceive in his brain that he wants to play it. Such perceptions motivate the child to do something, that is, move to take it. As a result of the movement, the child managed to get what he got in the way of taking the toys that interest him.

There are two types of motor skills that develop in early childhood that is fine motor and rough motor. In childhood motor skills develop in line with the development of cognitive abilities of children (Piaget, 1952 in Papalia and Feldman, 2004: 85). In line with the opinions of the experts above, Samsudin (2005: 29) reveals that "Cognitive development and motor development are constantly interacting, cognitive development is stronger depending on the intellectual ability of the interaction process". Teachers should develop the most appropriate teaching methods for children, especially kindergarten teachers. The development of the method is based on characteristics of child growth and development, where experts often refer to it as DAP (Developmentally Appropriate Practice).

The gross motor skills referred to in this study are closely related to basic motion in the basic motion observation and evaluation guidelines according to Suherman (2008 in Yusuf, 2011: 20), namely: (1) Running which has basic motion components including: limb motion viewed from the side, arms, and leg movement seen from behind. (2) jumps that have basic motion components include: arms, togok, and limbs. (3) Throws that have basic components include: arms and limbs. (4) Capture has basic motion components including: head, arms, and hands. (5) Kicking has basic motion components including: arm and limbs.

The task of physical development in the form of coordination of body movement, such as running, on tiptoe, jumping, hanging, throwing and catching, as well as maintaining balance. This activity is necessary in improving the co-ordination skills of rough motor movements. In a 4-year-old child, the child is very excited about the challenging physical activities for him, such as jumping from high places or hanging with his head hanging down. At the age of 5 or 6 years the desire to do these activities increases. Children at this time enjoy race events, such as bicycle race, race run or other activities that contain hazards.

According to Santrock (2012: 225) At the age of 4 years, fine motor coordination of children has increased and become more precise and by the age of 5 years fine motor coordination will increase. Samsudin (2005: 118) says that fine motor is the ability of children to move by using smooth muscles (small) such as writing, squeezing, drawing, grasping, arranging blocks and inserting marbles. The purpose of fine motor development at the age of 4-6 years is the child is able to develop fine motor skills associated with the movement skills of both hands, able to move the limbs associated with finger movements such as readiness to write, draw and manipulate objects, and hand activity and able to control emotions in fine motor activity.

The development of fine motor of kindergarten children is emphasized on the coordination of fine motor movement in this case relates to the activity of putting or holding an object by using fingers. At the age of 4 years the coordination of fine motor movement of the child is very developed, even almost perfect. Nevertheless this child of age is still having difficulty in arranging the blocks into a building. This is caused by the child's desire to put the beam perfectly so that it sometimes undermines the building itself. At the age of 5 or 6 years the coordination of fine motor movement develops rapidly. At this time the child has been able to coordinate motion visual motion, such as 
coordinating eye movements with the hands, arms, and body simultaneously, among others can be seen at the time of writing or drawing children.

\section{Conclusions}

Child's motor or movement by the child's entire body. Increased motor ability of children can be defined as the development of the elements of maturity and control of gestures, and these developments are related to the development of motor centers in the brain. Movements made by the whole body of the child can be distinguished between the gross movement (motorikkasar) and smooth movement (fine motor).

Local wisdom owned Indonesia one of which is a traditional game. Traditional fashion owned by every region in Indonesia makes the cultural and historical identity owned by every region in Indonesia. So it can be said that the traditional game is one form of social interaction that hereditary. When viewed from the karatkteristik traditional game is strongly influenced geographical location and culture of local culture. Traditional games are therefore played to fill vacancies during school holidays, livestock cattle, waiting for harvest, festivities, and also for filling activities at custom parties.

Modern games or game manufacturers tend to be more practical that does not require more body movement, this practicality makes the child lazy, on the other hand the game requires enough money to get the gear. Gradually the existence of this modern shrine obliterates the values of traditional games as to which values are contained in traditional games which one of them as a form of building social interaction, while the modern game is more individualistic.

\section{References}

Corey, G. (2012). Theory and Practice of Counseling and Psychotherapy. Belmont: Brooks and Cole.

Drewes, A.A. dan C.S. Scheifer (Ed). (2010). School-Based Play Therapy. New Jersey: Jhon Wiley and Sons.

Gerald, K. dan D. Gerald. (2012). Konseling Anak-Anak Sebuah Pengantar Praktis. Jakarta: PT Indeks Permata Puri Media.

Gustiana, A.D. (2011). Pengaruh Permainan Modifikasi Terhadap Kemampuan Motorik Kasar Dan Kognitif Anak Usia Dini (Studi Kuasi Eksperimen pada Kelompok B TK Kartika dan TK Lab. UPI). Jurnal PAUD Edisi Khusus. Bandung: FIP UPI Bandung.

Maulana, M.A. (2014). Model Bimbingan Kelompok Berbasis Budaya Jawa Dengan Teknik Permainan Untuk Meningkatkan Interaksi Sosial Siswa Smp Kota Semarang. Jurnal Bimbingan dan Konseling. Semarang: Program Pascasarjana Universitas Negeri semarang.

Papalia, O. dan Feldman. (2010). Human Development. Jakarta: Salemba Humanika

Plummer, D.M. (2010). Helping Children to Cope with Change, Stress and Anxiety A Photocopiable Activities Book. London: Jessica Kingsley Publisher.

Prayitno dan E. Amti. (2013). Dasar-Dasar Bimbingan dan Konseling di Sekolah. Jakarta: Rineka Cipta.

Santrock, J.W. (2012). Life Span Development. Jakarta: Indeks Media

Samsudin. (2005). Pengembangan Motorik di Taman Kanak-kanak. Jakarta: Fakultas Ilmu Keolahragaan Universitas Negeri Jakarta.

Seriati, N.N. dan N. Hayati. (2012). Permainan Tradisional Jawa Gerak dan Lagu Untuk Menstimulasi Keterampilan Sosial Anak Usia Dini. Jurnal Pendidikan Anak Usia Dini. Denpasar: FIP UNDHIKSA.

Sukamti, E.R. (2011). Perkembangan Motorik Kasar Anak Usia Dini Sebagai Dasar Menuju Prestasi Olah Raga. Jurnal Fakultas Ilmu Keolahragaan UNY. Yogyakarta: FIK UNY. 
Surya, M. (2005). Bimbingan dan Konseling di Sekolah. Bandung: PT. Alfabeta Pustaka. Sutoyo, A. (2009). Bimbingan dan Konseling Islami: Teori dan Praktik. Semarang: Widya Karya. Yusuf, S.L.N. (2010). Psikologi Perkembangan Anak dan Remaja. Bandung: Remaja Rosdakarya. 